\title{
FIRST LANGUAGE INTERFERENCE IN ENGLISH SPEAKING PERFORMANCE OF UNIVERSITY STUDENTS OF MUHAMMADIYAH SORONG (UMS)
}

\author{
Rizal Akib \\ Department of English Education, Faculty of Teacher Training and Education, \\ University of Muhammadiyah Sorong \\ Email: rizalakib.ums@gmail.com
}

\begin{abstract}
The research objective was to find out the interference of first language occurs to English Speaking Performance at English department Students in University of Muhammadiyah Sorong and to find out what kinds of first language interference occurs to English Speaking Performance at English department Students in University of Muhammadiyah Sorong. The research design applied qualitative descriptive analysis which used to analyze the data taken from the real speaking of respondents that recorded on the progress of data collection. Numbers of respondent are asked to give their opinion or responses on selected theme provided on this research to elicit their real speaking performance which is recorded and analyzed. The result of this research revealed that there were first language interference occurred at English department students in university of Muhammadiyah Sorong and several kinds of first language interference were occurred on Word Pronunciation (54\%), Dialect (38\%), and Word Repetition (8\%) which based on 15 respondent and total populations from three semesters of English Department in University of Muhammadiyah Sorong.
\end{abstract}

Keywords: first language, first language interference, first language study, speaking performance

\section{INTRODUCTIONS}

Through English people can communicate with other people in other country which is extremely different on knowledge, thought, culture and the way they live. It was a result of English as a global language to connect people over the world and makes them easy to interlacing a relationship and developing their advancement in science and technology which are being claimed toward the future. For those who Learns English as a second language, it is because they need English for several functions such as education, job, academic, or business. Another reason is to develop their advancement in science and technology which are being claimed toward the future. 
Native speakers of English exactly will not get difficulties to learn English because it was acquired over there and it has become their first Language. The problems exactly come from people who learn English as a second language or called ESL learner. It is being a second language which is new on structure, pronunciation, and also in accent. First Language of ESL Learner is also a particular problem for them. It needs great attention to learn second language like English, as we know that English has a complicated rule such as structure and pronunciation which is far different with first Language of ESL learner. Sinha, et all (2009), on her research entitled interference of first language in the acquisition of second language conclude that the first language interferes in the acquisition of the second language and it is applicable universally.

Learn new language such as English is often focused on the speaking performance. All ESL Learner are intended to perform their English speaking performance close to Native speaker style. It raises a several questions that, is this possible to do that?. While we know that there is first language which is different on structure, pronounce, style and accent which would interfere the English speaking performance. Is there any interference of first language to second language?

Based on all questions above the researcher would like to investigate the English Learner of University students at English Department in University of Muhammadiyah on a form of research.

The problem in this research could be formulated in the form of several questions as follows: (i) Is there any interference of first language to students speaking performance? (ii) What kinds of first language interference occur in English speaking performance?.

\section{RESEARCH METHOD AND DESIGN}

This chapter presents the methods and procedures that the writer follows to pinpoint the interference of first language to the English speaking performance. The research method applied qualitative descriptive analysis approach to analyze all data has been collected. Using purposive sampling technique, the subject of this study will be applied for 15 students of English Department which is selected on several Semester in University of Muhammadiyah Sorong, they are from third, fifth and seventh semester. The respondent satisfy the following criteria: 1) They are students of English 
Department; 2) They have never been to an English Speaking Country; 3) They Have Passed the class Speaking I and II; 4) They have learned and Used Indonesian since their childhood.

The research procedure applied on several steps as follows:

1. 15 respondents separated into 3 groups consist of 5 respondents each groups.

2. Data collection conducted on 3 stages depends on groups and time as seen on the table below. Each respondent asked to give their comment or opinion about the selected themes which is available.

\begin{tabular}{lll}
\hline Day & Respondent Grade & $\begin{array}{l}\text { Number or } \\
\text { Respondent }\end{array}$ \\
\hline $1_{\sim}^{\text {st }}$ & $3_{m}^{\text {th }}$ Semester & 5 \\
\hline $2_{\sim \infty}^{\text {sd }}$ & $5^{\text {th }}$ Semester & 5 \\
\hline $3_{\sim}^{\text {th }}$ & $7_{m}^{\text {th }}$ Semester & 5 \\
\hline
\end{tabular}

3. Each student should give their comment on English for about 3 minutes to a theme that is selected by them. The researcher set up a group of discussion to the respondent based on selected theme which is intended to get the real speaking performance of the respondent. The researcher will ask to all respondent to speak up about a theme which they could response. All themes are constructed to elicit English speaking performance of all respondents. The speaking performance of respondent was recorded by the researcher using recorder device.

Data Analysis

All sample of data which has been collected from respondent discussion on the form of audio recording, furthermore described into qualitative analysis. First, the analysis of L1 interference focused on the extent of Students L1 Segment of speaking performance such as Dialect, Intonation, Word Pronunciation, grammar, word repetition and word Stress. Overall data analyzed using qualitative analysis to find out the interference of L1 to English speaking performance. The data has been collected analyzed on several segment of speaking performance. 
Finally, the analysis of L1 interference done by listening and scanning the recording data of respondent than clarified any possible interference which occurred into segmental speaking performance such as Dialect, Intonation, Word Pronunciation, grammar, word repetition and word Stress as mention above.

\section{FINDINGS \& DISCUSSIONS}

The analysis of the interference data of the respondents speaking performance revealed various instance of speaking performance but the writer still focused on finding the interference of L1 to English speaking performance only. The interference has shown by all respondent come on various English studies especially English Speaking study. The finding of the interference classified into two major categories, they are: L1 Interference and non-L1 interference (Target Language interference).

First, L1 interference found are Dialect (Word Stress and Intonation), Word Pronunciation, Grammar and Lexical Second, L2 Interference found is Vocabulary mastery, Speaking anxiety and word reduplication. Both L1 and L2 interference was found to all respondent's English speaking performance but we stay to discuss about the L1 interference only.

\begin{tabular}{|c|c|}
\hline $\begin{array}{l}\text { First Language } \\
\text { interference }\end{array}$ & $\begin{array}{l}\text { Number of } \\
\text { Occurrences }\end{array}$ \\
\hline Dialect & $\begin{array}{l}6 \text { (ESD, SKM, } \\
\text { ANS, DNK, NSI, } \\
\text { RND) }\end{array}$ \\
\hline Word Pronounce & $\begin{array}{l}\text { S (ESD, SKM, } \\
\text { ANS, ANR, SNI, } \\
\text { ETM, NSI, SBN) }\end{array}$ \\
\hline Grammar & $\begin{array}{l}3 \text { (SKM, SNI, } \\
\text { SNII) }\end{array}$ \\
\hline Lexical & $\begin{array}{l}5 \text { (SKM, ANS, } \\
\text { RNI, DMK, IRMD) }\end{array}$ \\
\hline
\end{tabular}

Based on 15 data, researcher found there were L1 interference occurred on Learner speaking performance in this researcher, there are 6 occurrences on Dialect aspect, 8 occurrences on Word Pronunciation, 3 occurrences on Grammar and 5 occurrences on Lexical. It shows there were L1 interferences on English second language learner to their English speaking performance even though the number is not significant but the possibility of L1 interference on English speaking performance absolutely could occurred. 
First language interference to second language was a long chapter being studied by all linguistic expert and language researcher, First language interference which has been found by the researcher on this research related to pronunciation study.

First is Dialect, it was a complicated subject to talking about because here in Indonesia there are many dialects available as a result of various ethnic located in Indonesia. Here in Sorong town people comes from various ethnic of Indonesia, so various dialect of English learner L1 are also is a factor would be interfere their English speaking performance. In case of this research, all respondents are also comes from various ethnic of Indonesia for instance, Javanese, Bugines, Ambones and Papuaneese, so various dialect which is found on this research is occurred.

For example of interference on dialect see both of these respondent transcripts below:

First:

"I want to get scholarship from ee.. like united state because that is my dream to go abroad"

Second:

"he didn't know about Indonesia he didn't know about their work he didn't know about what this is and they don't know about anything for example like yaahh. . if we if we are students you like ee.. you know about Bali you know you you know about Papua I believe that they don't know about it because they haven't knowledge"

It was clearly heard that this respondent's rhythm and intonation still interfere the way how they speaks. This interference is clarifying the definition of interference which is state by Assimina (2003) that is interference is a communicative behavior for the first language influences the second language. Dialect has become a communicative behavior of English Learner in Sorong.

The second interference occurred on Word Pronunciation Aspect, the way learner pronounce English Word are extremely different on their L1 pronunciation. It becomes another study for English learner because their L1 Phonetic is very different of English Phonetic, even there several phonetic or sound which don't recognize on English learners first language for example: word ; Think $/ \theta \mathrm{Ink} /$ English learner in this case Indonesian doesn't recognize sound $\theta$ and also no one word in Indonesian language place $/ \mathrm{h} /$ after $/ \mathrm{t} /$. the affect from this case several respondent is pronounced the word as 
the way they pronounced their L1 by omit a character on the word such as Think $=$ ting ; great $=$ gret $;$ Work $=$ work $;$ about $=$ abot and many others. This case is also proving one of interference theory which is stated that interference of L1 on L2 occurs in many components levels like phonological, lexical, and grammatical.

Refer to Zhang \& Yin's (2009) statement that a particular sound which does not exist in the native language can therefore pose a difficulty for the second language learners to produce or some times to try to substitute those sounds with similar ones in their mother tongue. These sounds include both vowels and consonants. In the other hand, respondent may not have reference on English native speaker dialect, so that also let them to produce that speak in line with their dialect as displayed on several findings above.

Moreover, this interference also support the finding of previous study which is conducted by Prananingrum and Kwary (2006), they found that there are seven English consonants that are transferred incorrectly by the respondents, i.e. $[\mathrm{k}],[\mathrm{z}],[\mathrm{v}],\left[\int\right],[\theta]$, $[ð],[\mathrm{n}]$ and $[\mathrm{d}]$, as occurred on respondent code SMI, he pronounced word future /'fju'.t $\int$ o r / incorrectly.

However, the English consonant sounds that pose major difficulties for the respondents are only for the sound $[\mathrm{z}],[\mathrm{v}]$, and $[\mathrm{k}]$. The sound $[\mathrm{z}]$ in the word-final position is considered difficult since all of the respondents pronounce the sound incorrectly. In addition, unlike English which has the sound [z] in word-final position, Indonesian only has the sound $[\mathrm{z}]$ in word- initial and medial and never occurs in wordfinal, therefore they tend to produce $[\mathrm{s}]$ for $[\mathrm{z}]$. Furthermore, the nonexistence of the sound $[\mathrm{v}]$ in Indonesian sound system apparently influences the production of English sound $[\mathrm{v}]$; as a result, the respondents produce [f] for [v]. Since it is hard to hear the sound [k] in word- final of ask especially when it is produced in a fast speech; it is not pronounced by all of the respondents in this study.

Also on Sinha, et all's (2009) research, showed that Asian students (Chinese, Indian and Korean) felt more difficulty in English phonological awareness tasks than native English speaking students. The reason behind this could be various like: 1) While learning second language (L2) alphabetical shapes and structures of first language (L1) would create interference; 2) In schools, teachers might not appropriately 
make them do practices or exercises in the Acquiring (L2) language; 3) Medium of instruction and communication in schools or colleges are mostly held in first language. It seems likely occurred to this research respondent because they also are Asian.

The third interference was occurred on grammatical aspect of English, as state above interference of L1 on L2 occurs in many components levels like phonological, lexical, and grammatical. See the example below:

Incorrect form : "Introduce they are our culture"

Correct form : Introduce them our culture

The respondent error to place the correct pronounce in the sentences because of different structure of respondent's first language and English structure.

"Little-little" "Near-near"

All is occurred because Learner started by assuming that L2 is same or similar with L1 on structure. Here are the way they construct L1 and L2 in this case of list above

L1 $($ sedikit-sedikit $)=$ L2 $($ little little $)$

L1 (dekat-dekat) = L2 (near-near)

Instead on English there was no one word repeat like the respondent did on Indonesian language. In addition, this interference seem likely on Baljit (1999) conclusion, baljit conclude that the learners have used some L1 structures to produce appropriate responses in L2, producing semantically acceptable texts. Subsequently, the learners have also used L1 structures interchangeably with L2 structures, producing inappropriate L2 responses, interference of L1 on L2. Also she said that this has been clearly indicated in her study where the second language learners have adopted their L1 structures to help them in their L2 texts. The number of Grammar as a result of L1 that interfere English Speaking performance in this research is small showed by the findings but it doesn't mean there will not be interference on Dialect aspect.

The last interference which found on this research is Lexical aspect of English, see the example below:

First:

"I think I choose the teacher" 
In sentence above respondent try to interpret his first language in lexical way, its caused by respondent often speak on her first language, for example: "saya, pikir saya pilih", she tried to transfer into English sentence lexically.

Second:

I wanna be a success enterprise Park man

More good for them

Respondent tried to interpret both of these words in respondent first language as

follows: Pengusaha : enterprise

Tukang Parkir : Parkman

Lebih baik untuk mereka : more good of them

Instead of:

Pengusaha : Bussinesman Tukang Parkir : Park keeper

Lebih baik untuk mereka : better for them

Third:

Correct $\quad:$ I didn't get hurt

Incorrect : "I don't feel ill"

Respondent tried to interpret word below in respondent first language as follows:

Sakit : ill

Instead of:

Sakit : hurt/ pain

Fourth:

"Most lack"

Respondent tried to interpret the phrase above as the way she speak in her first language: Sangat kurang Instead of Very less

Fifth:

"Three times a day we eat"

On her first language he could interpret the sentence above : tiga kali kami makan sehari Instead on English structure: we eat three times a day

This interference shows that all respondent tend to transfer structures and patterns from their first language to the English language.

Finally all findings in this research were proved that L1 interference could 
occurred on several aspects to the English speaking performance. Despite there were some L1 interference found in which they became the researcher focus, it seems to be unavoidable that reveal interference occurred not because of L1 interference such as vocabulary mastery and speaking anxiety.

First is Vocabulary Mastery, This was not a factor could be included on L1 interference, all second language learner should learn English step by step and mastery English vocabulary is a difficult one and normally spend a lot of time to mastery many English vocabulary. Lack of vocabulary in English Speaking always occurs not because our L1 interference but it related to our method how to learn English especially to mastery many English vocabulary; second is Speaking anxiety, this is a second problem also and absolutely occurred during the research. All of respondent were being anxiety while their speaking performance is recorded. It could be listen on data recording, for example sound "ee", and "ehm" is produce by their anxiety to speak. This thing also is excluded from analysis and it was not produced by L1; the last is Word Reduplication, actually it is probably occurred as a style of respondent speaking performance or caused by the anxiety also.

\section{CONCLUSIONS}

First, this research proved that there were some interference occurred on student's English speaking performance. Second, this research also proved that the interference that occurred are Word Pronunciation (36\%) aspect is large than Dialect (27\%), the Grammar (14\%) and the Lexical (23\%) which based on 15 respondent and total population from three semester of English Department in University of Muhammadiyah Sorong.

\section{Suggestions}

First language interference was not an obstacle for all English students to always learn and practice their English to become a good English speaker that could make student's English speaking performance close to native speaker performance. After knowing the first language could be interfere students speaking performance, all people who involved on English learning process especially lecture and students should construct an attempting to minimize the as interference. 
In this opportunity researcher would give several suggestion. Lecture should increase their teaching method for Pronunciation subject, Second language acquisition and sociolinguistic subject; this could increase students understanding to English. All students should evaluate and practice their English speaking performance in order to increasing their English speaking ability and performance regularly. Also in this case of English speaking performance, it would be better if university should determine standardization for English speaking proficiency special for Muhammadiyah University.

Finally this research could be continued with enlarge the number of population for further research, especially for all English students on English department in University of Muhammadiyah Sorong who want to fulfill the same final project like this because researcher aware that this research is not the perfect one and still less on the number of respondent and data analysis.

\section{REFRENCES}

Avanika Sinha, Niroj Banerjee, Ambalika Sinha and Rajesh Kumar Shastri. 2009. Interference of first language in the acquisition of second language. Journal of Psychology and Counseling Vol. 1(7), pp. 117-122.

Baljit Bhela. (1999). Native language interference in learning a second language: Exploratory case studies of native language interference with target language usage. International Education Journal Vol 1, No 1. 22-31.

Bennui, Pairote. (2008). A Study Of L1 Intereference In The Writing Of Thai EFL Students. Malaysian Journal Of ELT Research, Vol 4, Pg.91

Briere, Eugene. J, (2008). An investigation of Thai interference in selected American phonemes. University of Southern California.

Imoleayo, Olutekunbi Bolatito (2011). Mother tongue interference in english news cast: a case of a kwara television news. Department of English, Faculty of Arts, University of Ilorin

[online] Code Switching as a Countenance of Language Interference, available online on: http://iteslj.org/Articles/Skiba-CodeSwitching.html

[online] speaking topics, available on web: http://www.eslgold.com/speaking.html

[online] First language definition, available on web: http://en.wikipedia.org/wiki/First_language.html

[online] Second-language acquisition, available on web: http://en.wikipedia.org/wiki/Second- language_acquisition.html

[online] Second language, available on web: 
http://en.wikipedia.org/wiki/Second_language.html

Papadimitriou Assimina. Interference of greek learners' native language in their written performance of english verb tenses. The University of Edinburgh. (2003).

Prananingrum \& Kwary (2006). L1 influence on the production of L2 sounds: case study at the English diploma program, Airlangga University, Indonesia.

Petra Skoog (2006). Native Language Interference: A study of interference patterns in Swedish students' English writing. Estetisk-filosofiska fakulteten , Karlstads Universitet

Qaid, Yahia. A (2011). A study of Arabic Interference in Yemeni University Students' English Writing. Language in India Journal, Vol 11:4, pg.28

Thornton, John G (2009). Learning English as a second language in South Korea: Perceptions of 2nd year college and university students and their English speaking instructors. Education of Second Language Learning at the Graduate School of the University of Southern Queensland

Zhang \& Ying (2009). A Study of Pronunciation Problems of English Learners in China. Asian Social Science Journal. Vo.5, No.6 2009 pg. 142 